\title{
Dedication Names of Ancient Churches in the Counties of Durham and Northumberland
}

\section{By John V. Gregory}

To cite this article: By John V. Gregory (1885) Dedication Names of Ancient Churches in the Counties of Durham and Northumberland, Archaeological Journal, 42:1, 370-383, DOI: 10.1080/00665983.1885.10852180

To link to this article: http://dx.doi.org/10.1080/00665983.1885.10852180

冓 Published online: 15 Jul 2014.

Submit your article to this journal $[\pi$

Q View related articles $\sqsubset$ 


\section{DEDICATION NANES OF ANCIENT CHURCHES IN THE COUNTIES OF DURHAM AND NORTHUMBERLAND.}

By. JOHN V. GREGORY.

In treating of the church-names of Northumberland and Durham, there is a difficulty which meets us in some of the remote districts, to which more southern counties are less subject, namely, that many of our churches had originally no dedication-names at all. Some remain unnamed, and to others names have been given at a subsequent time, and we cannot always distinguish which are of modern origin. Mistakes, too, have been made through ignorance or neglect, so that the original ascription is sometimes doubtful.

Holy Trinity. Dedications in this name are found in the Trinity House chapel in Newcastle, and in the Northumberland churches of Embleton, Bewick, Cambo, Widdrington, and Whitfield; but the three last mentioned are probably all examples of names bestowed on rebuilding in modern times. The church of Bervick-on-Tweed was so named at its building in the seventeenth century. As regards Embleton the namo is not without doubt, for in Bacon's Liber Regis and in Randall's "State of the Churches under the Archdeaconry of Northumberland" (c. 1778) it is stated to be dedicated to St. Mary. The only undoubtedly ancient dedication to the Holy Trinity in Northumberland is the chapel of Bewick, which is not a parish church. In Durham, Washington is stated by Surtees (Hist. of Durham) to be dedicated to the Virrin. but in the Ordnance map it is called Holy Trinity, apparently without authority. In Gateshead was a hospital of the Holy Trinity, subsequently united with that of St. Edmund, and the chapel of St. Edmund, formerly in ruin, having been restored, is now the parish church of Holy Trinity. Sunderland Holy Trinity only dates from 1719.

Dedications of CHRIST church and St. Saviour are generally modern. CHRIsT's hospital at Sherbiurn was originally dedicated to Christ, the blessed Virgin, and Lazarus, and his sisters Martha and Mary. Christ church at North Shields is a seventeenth century edifice, built for the parish church of Tynemouth when the priory was ruined. Durham cathedral church, dedicated originally to the blessed Virgin and St. Cuthbert, was, at the dissolution of the priory by Henry VIII, re-named "the cathedral church of Christ and the blessed Virgin."

Hour Paraclete : The church of Kirlhaugh bears this remarkable dedication name, but it only dates from the time of a modern restoration.

Hour Cross is a medirval name, and is ascribed in Durham to the church of Ryton, and in Northumberland to Haltwhistle, Chatton, and the ancient but now demolished church of Wallsend. The festival of the dedication of a church often became a parochial holiday: Edward I. 
granted a fair to Haltwhistle for the day of "the Invention of the Holy Cross" old style, May 14.

St. MiohaEL, or St. Michael and All Angels, is a dedication of very frequent occurrence, especially in the northern parts of Northumberland. As this name is said to be a survival of Celtic Christianity, and as Northumbria was converted to the faith by the Celtic mission from Iona to Lindisfarne, it is not surprising that of all ancient church names in the old diocese of Durham, next to St. Mary, and not even excepting the great local name of St. Cuthbert, that of St. Michael most prevails. There are thirteen such dedications of ancient churches in Northumberland and six in Durham. Of these no fewer than nine occur in the northern part of Northumberland, which constitutes the archdeaconry of Lindisfarne, including the important church of Alnwick, now generally called St. Michael's, though St. Mary and St. Michael was its mediæval designation. Dockdington is also St. Mary and St. Michael. Ford, Hovick, Felton, Illerton, Ingram, Alnham, and Alwinton, are all St. Michael's, the four last named parishes forming a group adjoining each other. The ascription of Howick in Bacon's Liber Regis to St. Mary is, no doubt, an error. In the Tyne districts are Wark, Warden, and Newburn, and also the original dedication of St. John Lee, which, however, . was superseded at an early period. In the county palatine are the inportant churches of Houghtonle-Spring and Bishop-Wearmouth, together with Witton-Gilbert, Heighington, Bishop-Middleham, and Esh.

ALL SaINTs, a dedication so frequent in other parts of England, is not very prevalent in the North. We have in Northumberland, Newcastle, Rothbur'y, Rennington and Ryall, but the ascription of this name to Ryall only dates from its recent restoration. There are some remains of an ancient chantry chapel of All Saints at Morpeth. In Durham this dedication is given to four churches all in the south oast of the county, Stranton, Stciinton-le-street, Hurvoorth, and the ruined church of Sockburn, as well as its modern successor. Pensher (or Penshaw) is an eighteenth century foundation. There is also the doubtful dedication of Lanchester, either All Saints or St. Mary. It is now called St. Mary's, but the Lilier Regis (Bacon), Hutchinson, and Surtees give the name All Saints. Among the instances of parochial festivals coinciding with church dedication days is Rothbury fair on All Saints' day.

$\mathrm{S}_{\mathrm{T}}$. ANNe, the mother, according to tradition, of the blessed Virgin. Her name seems in some places to have been adopted in compliment to queen Anne, but this was not the case in Northumberland and Durham. St. Anne's, Newcastle, was neither founded nor rebuilt in her reign. At Ancroft, the parish name seems to have suggested the church name, a circumstance of which we shall find other examples at Simonburn, Alston and Edmundbyers. In the county palatine St. Anne's at Bishop Auckland is an old foundation.

St. Mary, or St. Mary the Virgin, the most popular of all church names, and not without scriptural reason, for "all generations" revere her "blessed" memory. In Northumberland, at least nineteen churches and chapels of ancient date are thus dedicater, besides others in which another saint is joined with the name of St. Mary, and also besides the doubtful case of Embleton, already referred to. Some are now extinct, as the Cistercian abbey of Newminster, the ruined chapel of Jesmoncl, and the Carmelite priory of Hulne. The former parish church of Hexham 
might also be mentioned, but in this paper vanished c'uurches which have not even been left in ruin are generally omitted. Though the ancient buildings are gone and sites changed, the hospital and chapel of St. Mary the Virgin at Newcastle still flourishes, and the name of the former parish church of Berwick has been revived in a new St. Mary's. The other churches of this dedication now existing in Northumberland are Holy Island, Belford, Wooler, Holystone, Lesbury, Ponteland, Bingfield, Stamfordham, Ovingham, Stannington, Morpeth, Woodhorn, Horton, and the Premonstratensian abbey, now parish church, of Blanchland. Whalton, sometimes said to be St. Mary the Virgin is probably St. Mary Magdalen, if it had any ancient name at all. The parish church of Holy Island is ascribed by Hutchinson and by Bacon's Liber Regis to St. John, which Raine (Hist. of North Durham) deems erroneous. At Holystone the church name suggests the connection with "our Lady's well," in which Paulinus baptized his converts of Upper Coquetdale. Another instance of a popular festival coinciding with the feast of the church dedication occurs in Morpeth fair held on Lady-day.

In Durham there are twenty ancient dedications in the name of St. Mary, viz:-Gateshead, Heworth, Whickham, Lanchester, Washington, Whitburn, Seaham, Easington, Monk-Hesleden, Norton, Long-Newton, Gainford, Denton, Whorlton, Barnard-Castle, Middleton-in-Teesdale, Staindrop, Cockfield, and two in Durham city, St. Mary-le-Bow and St. Mary-the-Less. Lanchester, as already stated, has been ascribed apparently in error to All Saints ; and Washington is probably St. Mary's and not Holy Trinity, if it had any ancient name at all.

Of joint dedications to St. Mary and another, there are six in Northumberland, and two or three in Durham, viz:-Alnwick, Doddington, Bolton, Lambley, Tynemouth priory, and Alnwick abbey, Chester-leStreet, Greatham hospital, and possibly (but not probably) Wolsingham. In these cases, though St. Mary may be placed first in order, it is often a prefixed and expletive name, and the other is the special name, as St. Mary and St. Cuthbert at Chester-le Street ; but in the case of St. Mary and St. Oswin at Tynemouth, St. Oswin was a later addition. In this paper these churches are classed under the second or special name.

St. JoHN тHE BAPTIST appears to have been more popular in ancient times than St. John the Evangelist, at least in Northumberland, where we have only one ancient St. John the Evangelist, while we have five named in honour of the Baptist. These are at Newcastle, Ulgham, Alnmouth, Edlingham, and Lowick. Ulgham "feast" on St. John Baptist's day (old style July 5) also shows the connection between popular festivities and church dedication. In Durham there are of this name St. John's Weardale (or Chapel in Weardale), Greatham and Egglescliffe (or Eaglescliffe). Finchale priory had the joint dedication of St. John the Baptist and St. Godric.

ST. PETER: Of names of apostles that of the apostolic primate has generally been the favourite; but it is somewhat remarkable that in the old diocese of Durham it was in ancient times surpassed in number of churches by St. Andrew, and in Northumberland, strangely enough, by St. Bartholomew. Nevertheless the earliest foundations in the north of England were dedicated to St. Peter. These were the Anglo-Saxon churches at Lindisfarne, where the priory ruins now stand, and the chapel which once existed in Bamburgh castle. St. Aidan's first church at Lindisfarne was a building of wood and thatch; and when, after 
having been burnt, it was rebuilt by his successor St. Finan (A.D. 651. 661 ) it was of similar materials, and it had then no dedication name. When Theodore of Tarsus, archbishop of Canterbury (668-690) was organizing what had been till his time mere mission stations into the established church of England, he visited Northumbria, and gave the first recorded church name in this district, in dedicating, as we are informed by Bede, the church of Lindisfarne in honour of St. Peter the Apostle. The chapel at Bamburgh, probably on the site where traces of the foundations still remain within the walls of the castle, is also mentioned by Bede as "the church of St. Peter in the royal city of Bebbanburgh."

The church of Norham, now St. Cuthbert's, was originally dedicated in the ninth century to St. Peter, St. Cuthbert, and St. Ceolwulf.

Existing ancient churches dedicated to St. Peter in Northumberland, are those of Chillingham, Long-Houghton Bywell. and Newbrough. The name of St. Peter's, now applied to a riverside part of Newcastle, is misleading; it was originally "Sir Peter's quay." " In Durham there are churches of St. Peter at Monk-Wearmouth, Elwvick Hall, Bishopton and Wolviston.

St. Benedict Biscop's twin monastic churches of Monk-Wearmouth and Jarrow had the joint dedication of St. PeTER aNd ST. PAUL, St. Peter being applied to Wearmouth, and St. Paul to Jarrow. This joint dedication was common in ancient times, and some churches, now St. Peter's, were originally St. Peter and St. Paul, who may be deemed to represent respectively the centre and the circumference of the apostolic circle. The juxtaposition of the two names is seen in the abboy church of St. Peter at Westminster and the cathedral chuch of St. Paul in London. There is one dedication to St. Peter and St. Paul in Northumberland, in the Augustinian priory church of Brinkburn, which after long lying in ruin has in recent times been repaired for Divine service; not to say "restored," though it is a model of what restoration ought to be.

ST. ANDREw being the patron saint of Scotland, the influence of his name has extended across the Border, which may account for the number of ancient churches dedicated to this apostle, seven each in Northumberland and Durham. The kings of Scotland held Northumberland at one period, and one church, St. Andrew's, Newcastle, is supposed to have been founded by the Scottish king, David I.

The most important church in the north of England, dedicated to St. Andrew, is the abbey church of Hexham, originally founded in the seventh century by St. Wilfrid, and though re-founcled in the twelfth century as an Augustinian priory, it has retained throughout its original dedication of St. Andrew, which is mentioned by Bede. It is remarkable that Wilfrid made his earliest devotions in Rome in the church of the monastery of St. Andrew on mount Cælius, a monastery now called after St. Gregory, by whom it was founded, and from whence he sent Augustine to England.

It frequently happens that several churches of the same name are found in proximity, and thus, following the example of Hexham, the neighbouring churches of Corbridge, Bywell St. Andrew, and the old church of Shotley now in ruins, are all cledicated to St. Andrew.

The two churches of Bywell, St. Andrew and St. Peter, are locally called the white and black churches. The fable of these churches 
having been placed together by two sisters who had quarrelled about the site may have been foreshadowed in the two baronies of Bywell. St. Andrew's, the church of the barony of Bolbeck, was appropriated to the Premonstratensian canons of Blanchland from whose white garments it was called "the white church ;" Bywell St. Peter's, the church of the barony of Balliol, was granted to the black-robed Benedictines of Tynemouth and Durham, and so acquired the name of "the black church."

Other ancient ascriptions to St. Andrew occur in Northumberland in the churches of Bolain and Bothal. Bolam is said to have been originally founded by the Iona missionaries. Heddon-on-the-Wall is ascribed to St. Andrew in Liber Regis (Bacon), but Randall gives St. Philip and St. James, which is accepted by local repute.

In Durham is the important collegiate church of St. Andrevu-Auckland, and also churches of St. Andrew at Lamestey, Dalton-le-Dale, Haughtonle-S7cerne, Salberge, Aycliffe, and Winston. Aycliffe is ascribed in Bacon's Liber Regis to St. Acca, which appears to be an example of place-name suggesting church name erroneously: Aycliffe was anciently written Accliffe and Aclif $=$ oak-cliffe.

ST. JAMEs. -Dedications to St. James may be assumed to refer to St. James the Great. In Durham are the churches of Castle-Eden, Hansterley, and Hunstanworth, and in Northumberland Shilbottle. In Liber Regis (Bacon), contrary to all local authorities, Tanfield is ascribed to St. James; it is properly St. Margaret. The Premonstratensian abbey of Alnwich was dedicated to St. James and the blessed Virgin.

ST. JoHN, or St. John the Evangelist, is represented by only one parish church in Northumberland, that of Meldon; and in Durham the churches of Dinsdale, Merrington, and the remarkable Anglo-Saxon church of Escombe. In modern churches St. John is the most popular of all names in this district. Sunderland St. John is of the eighteenth century.

St. MatrHew. - The church of Wolsingham is commonly understood to be dedicated to St. Matthew. It would appear that the Liber Regis and Hutchinson's History ascribing it to St. Mary and St. Stephen are inaccurate. The old fair day at Wolsingham is St. Matthew's day.

St. Thomas the Apostue is the dedication of the church of Stanhope, where also a fair is held on that saint's day.

The church of St. Thomas at Stockton was originally St. Thomas of Canterbury.

St. Philip and St. James. - The festivals of St. James the Less and of St. Philip are united together on May-day, which being also a popular holiday in the olden time was a likely day to be selected for the dedication of a church. Accordingly we have four ancient churches dedicated to St. Philip and St. James. Heddon-on-the-Wall, Whittonstall; and Rock in Northumberland, and Witton-le-Wear in Durham.

St. BaRtholomew.-It is remarkable that this ascription should have been so popular in ancient times in Northumberland. There have been eight ancient churches of this name in Northumberland, but only one in Durham. It is probable that although the name may have been given in honour of St. Bartholomew the Apostle, it was in some cases adopted from another Bartholomew, that being the name assumed by a native of Whitby called Tosti, on his becoming a monk of Durham, and who, following the example of St. Cuthbert, ultimately became a hermit on Farne 
Island, and is known as St. Bartholomew of Farne. He died about 1182, about which time many Northumbrian churches were founded.

At Tweedmouth, the township of Spital derives its name from an extinct leper hospital of St. Bartholomew; and this is also the dedication name of the church of Tweedmouth, which, though an eighteenth century rebuilding, is a twelfth century foundation.

The most ancient northern church dedicated to St. Bartholomew is that of Whittingham, portions of the present building being of the eleventh century. Newbiggin church is also of this dedication; and at these two places fairs are held on or about St. Bartholomew's day. Other churches of this name are at Long-Benton, Kirk-Whelpington, and $K i r \%$ Heaton. On the Ordnance map Long-Benton is erroneously ascribed to St. Andrew. Kirk-Heaton has also sometimes been called St. Andrew.

In Newcastle, St. Bartholomew the Apostle gave the name to the church of the great nunnery which once occupied the site indicated by Nun street.

In the county of Durham the ancient chapel of Croxdale was dedicated to St. Bartholomew.

St. Simon. The apostles St. Simon and St. Jude are the only two of the eleven whose names are not found in ancient churches of Northumberland or Durham, unless St. Simon be the name of the church of Simonburn, which it probably was not originally. Of other evangelists and apastles, St. Mark, St. Lulke, St. Matthias, and St. Barnabas are also wanting.

St. Stephen. There is a doubt already mentioned whether Wolsingham church is dedicated to St. Mary and St. Stephen, but the presumption is in favour of St. Matthew.

ST. PAUL is a favourite name for modern churches, being, next to St. John, the most frequent in these two counties. But in ancient times it was not so, being in fact extremely rare when not conjoined with st. Peter. We have in Durham one ancient St. Paul's in the celebrated church of the Venerable Bede at Jarroul, but it owes its name to the double dedication of St. Peter and St. Paul of Wearmouth and Jarrow as already mentioned. In Northumberland there is one ancient church of St. Paul, that of Branxton, but this, if an ancient ascription, has most likely been a contraction of 'St. Paulinus (see p. 378.)

St. Mary Magdalen : In Durham this name is given to the churches of Merlomsley, Hart, and Trimdon, and also to a ruined chapel at Durham; and in Northumberland to Mitford and Whalton. There is a question whether Whalton should not be St. Mary the Virgin, but Hodgson (Hist. of Northumb.) gives St. Mary Magdalen. Perhaps Mitford and Whalton, both very ancient foundations, were originally nameless; and Mitford acquired its name at a re-dedication after partial rebuilding, when it had become appropriated to the priory of St. Mary Magdalen, Lanercost; and the adjoining parish of Whalton seems to have adopted the same, for it is remarkable how church-names run in groups of adjacent parishes, as will be seen by comparing neighbouring churches dedicated to St. Andrew, St. Giles, St. Maurice, St. Michael, and others. There is a hospital of St. Mary Magdalen at Newcastle, but its chapel is dedicated to St. Thomas the Martyr.

The list of New Testament names is hele concluded, and those which 
follow are the Christian saints of later date. Of these the earliest we find in the old northern diocese is

ST. LaUREnce ; a Spaniard, archdeacon of Rome, who suffered martyrdom at Rome, A.D. 258. His name was brought into Northumbria by relics sent to king Oswy in the seventh century, and we have one parish church in each county to commemorate him, Pittington and Warkworth. The church of Warkworth was founded by Ceolwulf, king of Northumbria, about A.D. 736. A chapel of St. Laurence once existed at Newcastle, of which a few stones remain, and it has given name to the locality.

ST. George, of Cappadocia, martyred in A.D. 285. Being a Christian soldier he became idealized as a redressor of wrongs, the dragon slayer, and in the time of the crusades the patron of chivalry, and was adopted by Edward III, as the model of knighthood for the Order of the Garter, and hence St. George came to be considered the tutelary saint of England. The modern prevalence of St. George in church names is greatly due to loyal feeling during the Georgian era; but there are ancient churches dedicated to him, of which we have one in Durham, Micldleton St. George.

ST. Maurice, another soldier martyr, who suffered A.D. 286, at the place now called by his name, on the Rhone in Switzerland. Why he should be commemorated in Northumberland, in the two adjacent parish churches of Eglingham and Ellingham, does not appear. In Randal's list (1778) Ellingham is called St. Mary, but this is deemed inaccurate. There is a well of St. Maurice near the church. It should be noted, however, that Randal was himself vicar of Ellingham.

ST. Alban, the British protomartyr, A.D. 303, is commemorated in the church of Earsilon, which anciently belonged to the neighbouring priory of Tynemouth, and as that priory was subordinate to the great abbey of St. Alban's, the name has thus been chosen for Earsdon.

St. Maraaret has a church in the city of Droham, and another in the county at Tanfield. This name is probably not from the legendary St. Margaret, the virgin martyr of Antioch A.D. 306, but rather is in honour of the pious and noble-minded Anglo-Saxon princess, Margaret, wife of Malcolm Canmore, king of Scotland, and mother of David I. the founder of many churches and abbeys. She was born 1046. The estimation in which she was held in the bishopric is shown by her life having been written by a monk of Durham, probably Turgot, who was installed prior in 1087 . (Surtees Society, vol. 51). The christian name of Margaret continues one of the most prevalent in the district.

St. Catherine, virgin martyr of Alexandria, A.D. 307, whose legend represents a Christianized Minerva, had her name ascribed in Newcastle to the Maison Dieu of Roger Thornton, now the guildhall; and also in the county of Durham to a former chapel at Hylton.

ST. HELse, the Christian empress (d. 328), who founded the church of the Holy Sepulchre at Jerusalem and the church of the Nativity at Bethlehem. From the circumstance that her son, Constantine the Great, was in Britain when he succeeded to the empire, Helen, or Helena, was supposed to be a British princess. She was really a native of Bithynia; but the British tradition, revived probably in crusading times, made her name popular in this country. The churches dedicated to her memory in Northumberland are Cornhill (where is also a well of St. Helen), LonyHorsley, and Whitley-in-Hexhamshive; and in Durham, St. Helen- 
Aucklancl, and Kelloe, and a gateway chapel at Durham. In Kelloe church is a remarkable ancient cross sculptured with the legend of St. Helen.

ST. ANTHONY, the Egyptian patriarch of monachism (d. 356), gives name to a church in Newcastle of recent foundation, but the locality has, borme the name of St. Anthony's from olden times.

St. Nicholas, bishop of Myra, in Asia Minor, about A.D. 326. This is the well-known dedication name of the principal, now the eathedral, church of Newcastle. The name is found in seaport towns, the legendary St. Nicholas being the patron of the mariner, the toiler, the captive, the poor and the children. Two churches which were originally offshoots from St. Nicholas, Newcastle, bear the same name, Gosforth and Cramlington, and there is another in the north at Kyloe. In Durham the church of Boldon, and one in the city of Durham, are of this dedication.

St. Augustine. - The church of Alston, which, though in Cumberland, belongs to the diocese of Newcastle, is dedicated to St. Augustine. There is a local tradition that the church was founded by St. Augustine of Canterbury, but this is a mere plausible invention. It belonged to the Augustinian canons of Hexham, the chief rules of whose order were derived from the great St. Augustine, bishop of Hippo (d. 430), and the ascription may thus be derived from its connection with Hexham; but perhaps the parish name, which is locally pronounced "Auston," may, like Simonburn and Ancroft, have suggested the church name.

ST. Patrick. - The church of Lambley in South-Tynedale, where there was an ancient nunnery, is dedicated to St. Mary and St. Patrick. Why the name of the apostle of Ireland should be found in this remote Northumbrian locality does not appear. It should be remembered, however, that St. Patrick (d. 465) was not himself an Irishman, but a native either of Britain or Gaul.

St. LEONARD (d. 559) a Frankish saint, the patron of captives. Several ancient and vanished hospitals, as those at Alnwick in Northumberland, and Butterby in Durham, were dedicated to him.

ST. Brandon, to whom the church of Brancepeth is dedicated, was an Irishman, who is said to have voyaged to America, nearly 1000 years before Columbus. He founded and presided over the abbey of Clonfert, and died in 577. I can discover no reason why this saint was chosen in the bishopric of Durham. The dedication is undoubtedly a very ancient one, being mentioned by Reginald of Durham in the twelfth century as the name of an earlier structure than the present church. The derivation of Brancepeth from the "path" of the legendary "brawn" is mythical. The similarity of the name of the saint with the place name, and the identity of the name with that of the adjacent village of Brandon, suggests that Brancepeth is "Brandon's peth"; the Anglo-Saxon paeth, represented in our modern word path, had also the meaning of a dene or valley (see Luke xvi, 26, in Lindisfarne and Rushworth gospels, Surtees Society, vol. 43.)

St. Mungo.--The church of Simonburn is said to be dedicated to St. Simon. This has obviously been suggested by the name of the village, and is of later date than the first foundation of the church. The name Simonburn is not from any one called Simon, but from Sigmund an Anglo-Saxon warrior. The church is one of the most ancient foundations in the county of Northumberland, having, according to tradition, been 
founded by the disciples of Kentigern, otherwise Mungo, bishop of Glasgow, who died 601. A well in the vicinity of the church called "Muggers' well," appears to be a corruption of "Mungo's well." The ancient dedication, if any, being probably St. Mungo, that name has lately been resumed. Mungo was pre-eminently the saint of Tweeddale and Clydesdale, and his name is associated with some churches in the Scottish border counties which are among the oldest in that district.

St. Gregory, or Gregory the Grent, bishop of Rome, 590-604. One of the missionaries whom he sent to assist Augustine in preaching the Christian faith to the Anglo-Saxons was Paulinus. Many hundreds of Northumbrians were baptized by Parlinus in the river Glen, where now is the parish of Kirk-Newton, and the church of that parish, which is a twelfth century foundiation, is dedicated to St. Gregory.

St. Paulinus, came to England in 601, and became bishop of the Northumbrians in 625 . In the same district where he baptised his name is found, between Glendale and the Tweed, in Pallinsburn (= Paulinus'burn); and in the adjacent parish of Branxton the church is dedicated to St. Paul, which appears to be a contraction of St. Paulinus. There is a similar instance in the city of Lincoln, where Paulinus was also occupied as a mission preacher, and the church named in his honour is now shortened into "St. Paul."

St. Edwin, the convert of Paulinus, and the first Christian king of Northumbria (d. 633) is commemorated in the church of Coniscliffe on the Tees. Coniscliffe means "King's Cliff," so that there is evidently an ancient connection between the names of church and parish.

St. OswaLd, king of Northumbria, 634-42, who established Aidan the monk of Iona in the see of Lindisfarne, gives name to a little church St. Oswould's, a few miles north of Hexham, which stands on the site where, in A.D. 634, this king fixed the standard of the cross around which he and bis army made their prayer on the eve of battle against the Cymric chief Cadwallader. The place was named Hefenfeld, the Heavenly-field, and the original church on the site was built to commemorate Oswald's victory. In the city of Durham, the church of St. Oswald crowns the height opposite the cathedral church of St. Cuthbert, and his name also occurs in the Nine Altars chapel of the cathedral church. In art St. Cuthbert is represented bearing the head of St. Oswald, the head of Oswald having been placed in the coffin or shrine of Cuthbert at Lindisfarne.

ST. AIDAN.-It is a matter of some surprise that there is only one ancient church in Northumberland and not one in Durham, named from this distinguished missionary bishop, the real founder, with the aid of king Oswald, of the Christian church in the northern half of England. It is remarkable also that while historians dwell upon the successful mission of Augustine at Canterbury, there seems, till recent times, to have been a want of due appreciation of that of Aidan at Lindisfarne, notwithstanding that it was a permanent success in the north, which that of Paulinus had not been. And if among southerns Aidan has been overshadowed as a missionary by Angustine, among northerns he has been overshadowed as a saint by Cuthbert. As he was the first bishop of Lindisfarne (635-51), the palatinate bishops of Durham might as well have been called St. Aidan's successors, as successors of St. Cuthbert. 
That Cuthbert should have been more honoured than Airlan is characteristic of the middle ages, when monastic sanctity was more esteemed than missionary enterprise. But Aidan was a Gael, and in comparison with Cuthbert suffered from the disadvantage of being to the Anglo-Saxons a foreigner. He died at Bamburgh, and hence the church of that parish is called St. Aidan's, the only one so dedicated, unless Haltwohistle is another. Haltwhistle is classed as Holy Cross, but Hodgson (Hist. of Northum.) gives St. Aidan, which appears inaccurate. In the Nine Altars at Durham, the name of St. Aidan occurs.

Sт. Oswin, a humble-minded Christian monarch, king of Deira, murdered A.D. 651, and buried or enshrined at Tynemouth, of which he is called the patron saint. The priory church of Tynemouth was dedicated to the blessed Virgin and St. Oswin king and martyr.

Sт. HILDA, princess of Northumbria and abbess of Whitby (d. 680). Her memory is preserved in the names of the fine old storm-beaten church of Hartlepool, and in the principal church of South-Shields, with both which localities she was connected, having first established a small nunnery between South Shields and the Wear, the site of which is now unknown, and afterwards a more important one at Hartlepool, before she finally removed to Whitby.

Sт. EввA, sister of St. Oswald (d. 684) is commemorated in the church as well as in the place-name of Ebchester, where she founded a small monastery among the ruins of the Roman station on the Derwent. She afterwards founded and was abbess of Coldingham in Berwickshire, where also her name survives in St. Abb's Head. A modern church on the Northumbrian coast at Beadnell is named St. Elbba's from an ancient chapel once existing on an adjacent promontory called "Ebb's Snook."

Sт. Сutнвеrт, shepherd of Lauderdale, monk of Old Melrose, and successively prior and bishop of Lindisfarne, died at his retreat on the Farne island in 687, having filled the see of Lindisfarne only two years. His great fame rests on the sanctity of his personal character, which has made him pre-eminently the saint of the old diocese of Durham. His special church is, of course, that wherein his remains were finally deposited in A.D. 999, the grand cathedral church of "the blessed Mary the Virgin and St. Cuthbert the bishop" at Dur'ham. Previously the relics of St. Cuthbert had been 113 years at Chester-le-street, which church is also dedicated to St. Mary and St. Cuthbert, and its thousandth anniversary was celebrated in 1883. In the palatinate, (which territory was "the patrimony of St. Cuthbert ") we have also the important church of Darlington, and the churches of Billingham, Redmarshall, and Satley, dedicated to St. Cuthbert; and Greatham hospital is St. Mary and St. Cuthbert. Reginald of Durham mentions that the monastic church of Lindisfarne, when reerected as a Benedictine priory at the end of the eleventh century, was in honour of St. Cuthbert. (Surtees Soc., vol. 1, p. 45.)

Islandshire, Norhamshire, and Bedlingtonshire, now parts of Northumberland, formerly belonged to "the patrimony of St. Cuthbert," and remained detached parts of the county palatine down to 1844, and of the churches in these districts, Norham, Car.ham, and Bedlington, and the chapel on Farne Island are dedicated to St. Cuthbert.

The other churches of St. Cuthbert in Northumberland are Elsdon, which was one of the resting places of the saint's body in the wander- 
ings of the monks, Bellingham (where also the saint's body rested, and where there is a well of St. Cuthbert mentioned by Reginald of Durham, c. 1150), Hebbron, Allendale, Haydon, and its modern successor at Haydon-Bridge, and Beltingham.

ST. WrLFRID.-This zealous prelate (d. 709) was the great churchbuilder of his day, and the remarkable crypt of Hexham still remains of the church which he founded there. There are two dedications to his name in Northumberland, the church of Kirk-Harle, and the ruined chapel of Guizance.

St. JoHn OF BeverLey (d. 721), at one time bishop of Hexham, gives his name not only to the neighbouring church of St. John Lee, but also in that contracted form to the parish itself. Here at one period of his life he dwelt in a hermitage on the hill where the church stands. The church was originally founded by Wilfrid, and at first named St. Michael's.

St. ACOA, the friend of Bede, who succeeded John of Beverley as bishop of Hexham (709-32) has already been referred to in connection with Aycliffe, p. 374.

ST. BEDE, commonly called the Venerable Bede (d. 735). - Why so saintly a person should not have had churches dedicated to his illustrious memory is difficult to understand. It can scarcely be because there was no papal authority for calling him "saint," for saints became so recognised at first by popular opinion sustained by merely the authority of the diocesan bishop. Cuthbert, and Aidan, and Hilda, and many others were not styled saints because of any record of Roman canonization ; which does not appear to have become exclusive till about the twelfth century. Though Bede is not commemorated in any ancient church dedication, his name was not without honour in the cathedral church of Durham. Near his tomb in the Galilee chapel was once an altar to his memory ; and in the chapel of the Nine Altars, the central altar was dedicated to St. Cuthbert and St. Bede.

St. Ceolwulf.-The church of Norham when first founded by Ecfrid, otherwise Ecgred, bishop of Lindisfarne (830-45) was in honour of St. Peter, St. Cuthbert, and St. Ceolwulf, (Surtees Soc., vol. 51). The latter was the king of Northumbria to whom Bede dedicated his history, and who spent the last twenty-seven years of his life as a monk at Lindisfarne, and died 764 .

St. GILEs, a French hermit, who died about 712, became a popular saint in England, but why he should be commemorated in this county is unexplained. We have of this dedication the church of St. Giles in the city of Durham, with which was also connected the neighbouring hospital of St. Giles at Kepier of which only a gateway now remains; and in Northumberland are the churches of Chollerton, Birtley in North Tynedale and Nether-Witton.

ST. EDmund, king and martyr (d. 870) from whom the town of Bury St. Edmund's in his kingdom of East Anglia is named. The name of St. Edmund occurs four times in the "bishopric." At Becurepcire, now Bearpark, the ruined chapel was St. Edmund the king, and a modern church revives the name. Edmundbyers has probably had the church name s:iggested by the place name or vice versa. A modern church of St. Edmund at Gateshecr? has succeeded to the narne of a hospital founded 1248, and then styled "the chapel and hospital of St. Edmund, king and confessor, and of the glorious bishop Cuthbert," and it $i_{S}$ singular that we meet with the name of the hospital two centuries late 
as "St. Edmund the bishop." The church of Sedgefield is called St. Edmund the bishop. The only episcopal St. Edmund is archbishop Rich of Canterbury (d. 1240) who was canonized as St. Edmund of Pontigny. I think it is open to doubt whether St. Edmund "the bishop," has not been a mistake for "the king."

ST. RoBert was the first abbot of Nevminster in Northumberland (died 1159). The abbey church, of which only the foundations now remain, was like all Cistercian churches dedicated to St. Mary, but in popular estimation the name of St. Robert was also associated with it.

St. Thомas a Becket, otherwise St. Thomas of Canterbury, or St. Thomas the Martyr (d. 1170), was very popular in mediæval times. The principal church of the town of Stochton-on-Tees, originally a chapel to Norton, was dedicated to St. Thomas of Canterbury, though now it appears to be generally called simply St. Thomas. The old and disused church of Grindon in the same part of the county palatine is also dedicated to St. Thomas à Becket. The chapel formerly on Tyne bridge end, and rebuilt in modern times on another site in Newcctstle, was dedicated to St. Thomas the Martyr ; and a hospital at Bolton in Northumberland was ascribed to the blessed Virgin and St. Thomas the Martyr.

ST. GoDrIc, the wandering pedlar of Norfolk, the pilgrim seaman, and finally the hermit of Finchale (d. 1179) has his name joined with that of St. John the Baptist in the dedication of the church of the ruined priory of Finchale, near Durham.

There still remain some churches which hnve either no declication names, or these names have been lost. In Northumberland are the ancient churches and chapels of Slaley, Halton, Dilston, Knaresdale, Corsenside, Throckrington, Secton-Delaval, Hartburn. Long-Hramlington, and Tughall (in ruins); and in Durham, Whitworth, Mugglesivich; Elton, and Embleton, and the chapels of Durham and Aucklund castles.

ALPHABEIICAL LISTS OF EXISTING CHJRCHES OF EARLIER DATE THAN THE PRESENT GENTURY, INGLUDING MODERN FOUNDATIONS REVIVING

\section{ANCIENT NAMES.}

\section{Authorities :-}

(B) Liber Regis (Bacon 1786), and where the name is not there given, or in case of a difference, the following are referred to-

(R) Randal's Stite of the Churches appended to Hutchinson's Hist. of Northumber. land, 1778.

(H) Hutchinson's Hist. of Durham, 1787.

(S) Surtees' Hist. of Durham, 1816, etc.

Where no authority is referred to, the name is given by common repute.

County of Northumberlayd, and wow the Drocese of Netfcastle.

Allendale, St. Cuthbert

Alnham, St. Michael (B)

Alnmouth, St. John the Baptist (B)

Alnwick, St. Mary and St. Michael (R)

Alston (Cumberland), St. Augustine (St.

Austin, B)

Alwinton, St. Michnel and All Angels (St.

Michael, B)

Ancroft, St. Anne

Bamburgh, St. Aidan (B)

VOI. XLII.
Beadnell, St. Ebba

Bedlington, St. Cuthbert (B)

Belford, St. Mary (B)

Bellingham, St. Cuthbert (R)

Beltingham, St. Cuthbert (R)

Berwick, Holy Trinity (B)

" St. Mary

(See also Tweedmouth)

Bewick, Holy Trinity (B)

Bingfield, St. Mary 
Birtley in North Tynedale, St. Giles

Blanchland, St. Mary the Virgin

Bolam, St. Andrew (B)

Bothal, St. Andrew (B)

Branxton, St. Paul

Brinkburn, St. Peter and St. Paul (St. Peter, R)

Bywell, St. Andrew (B)

"St. Peter (B)

Cambo, Holy Trinity

Carham, St. Cuthbert (B)

Chatton, Holy Cross (B)

Chillingham, St. Peter (B)

Chollerton, St. Giles (B)

Corbridge, St. Andrew (B)

Cornhill, St. Helen (R)

Corsenside, unnamed

Cramlington, St. Nicholas (R)

Doddington, St. Mary and St. Michael

Earsdon, St. Alban (R)

Edlingham, St. John the Baptist (B)

Eglinghan, St. Maurice (B)

Ellingham, St. Maurice (B), or St. Mary (R)

Elsdon, St. Cuthbert (B)

Embleton, St. Mary (B), or Holy Trinity.

Felton, St. Michael (B)

Ford, St. Michael (B)

Gosforth, St. Nicholas

Halton, unnamed

Haltwhistle, Holy Cross (B)

Hartburn, unnamed

Hatydon Bridge, St. Cuthbert (B)

Hebbron, St. Cuthbert

Heddon-on-the.Wall, St. Philip and St. James (R), or St. Andrew (B)

Hesham, St. Andrew (R)

Holy Island, St. Mary, or St. John the Evangelist (B)

Holystone, St. Mary the Virgin (St. Mary, B)

Forton, St. Mary

Howick, St. Mary (B), or St. Michilel (li)

Ilderton, St. Michael (B)

Ingram, St. Michael (B)

Kirk-Harle, St. Wilfrid (B)

Kirkhaugh, Holy Paraclete

Kirk-Heaton, St. Bartholomew

Kirk-Newton, St. Gregory (B)

Kirk-Whelpington, St. Bartholomew (B)

Knaresdale, unnamed

Kyloe, St. Nicholas

Lambley, St. Mary and St. Patrick (R)

Lesbury, St. Mary (B)

Long-Benton, St. Bartholomew (B)
Long-Framlington, unnamed

Long-Horsley, St. Helen (B)

Long-Houghton, St. Peter (B)

Lowick, St. John the Baptist

Meldon, St. John the Evangelist (R), (St. John, B)

Mitford, St. Mary Magdalen

Morpeth, St. Mary (B)

Nether-Witton, St. Giles (B)

Newbiggin, St. Bartholomew (B)

Newbrough, St. Peter (R)

Newburn, St. Michael and All Angels (St. Michael, B)

Newcastle, St. Nicholas (B)

" St. Andrew (B)
$\quad$ St. John the Baptist (St.
John, B)
All Saints (B), or All Hallows

$$
\text { (R) }
$$

St. Anne (B)

" St. Mary the Virgin

"St. Thomas the Martyr (R)

Norham, St. Cuthbert (B)

North Shields, Christchurch

Ovingham, St. Mary the Virgin (St.

Mary, B)

Ponteland, St. Mary the Virgin (St. Mary, B)

Rennington, All Saints (B)

Rock, St. Philip and St. James (B)

Rothbury, All Saints (B)

Ryall, All Saints

St. John Lee, St. John of Beverley (R)

St. Oswald's, St. Oswald

Sentrin-Delaval, unnamed

Shilbottle, St. James (B)

Simonburn, St. Simon (B), or St. Mıngo

Sialey, unnamed

Stamfordham, St. Mary the Virgin

Stannington, St. Mary (R)

Throckrington, unnamed

Tweedmouth, St. Bartholomew (B)

Ulgham, St. John the Baptist (St. John, R)

Warden, St. Michael (B)

Wark in Tynedale, St. Michael

Warkworth, St. Liurence (B)

Whalton, St. Mary Magdalen

Whitfield, Holy Trinity

Whitley in Hexhamshire, St. Helen

Whittingham, St. Bartholomew (B)

Whittonstall, St. Philip and St. James (R)

Widdrington, Holy Trinity

Woodhorn, St. Mary (B)

Wvoler, St. Mary (B)

\section{Codnty and Dincese of Durham.}

Aycliffe, St. Acca (B), or St. Andrew (H)

Barnard-Castle, St. Mary (B)

Bearpark, St. Edmund the King

Billingham, St. Cuthbert (B)

Bishop-Auckland, St. Anne (B)

Bishop-Middleham, St. Mich:el (B)

Bishopton, St. Peter (B)
Bishop-Wearmouri,h, St. Michacl (13)

Boldon, St. Nicholas (B)

Brancepeth, St. Brandon (B)

Castle-Eden, St. James (B)

Chester-le-Street, St. Mary and St. Cuthbert (B)

Cockfield, St. Mary the Virgin 
Coniscliffe, St. Edwin (B)

Croxdale, St. Bartholomew (S)

Dalton-le-Dale, St. Andrew (B)

Darlington, St. Cuthbert (B)

Denton, St. Mary (H)

Dinsdale, St. John (B)

Durham (cathedral church), St. Mary and St. Cuthbert

Durham, St. Giles (B)

" St. Margaret (B)
St. Mary-le-Bow (B)
$" \quad$ St. Mary-tlie-Less
St. Nicholas (B)
$\quad$ St. Oswald (B)
Masington, St. Mary the Virgin (St.
Mary, B)

$$
\text { Mary, B) }
$$

Ebchester, St. Ebba (B)

Edmundbyers, St. Edmund (B)

Egglescliffe, St. John the Baptist (B)

Elton, unnamed

Elwick Hall, St. Peter (B)

Embleton, unnamed

Escombe, St. John the Evangelist

Esh, St. Michael (B)

Gainford, St. Mary (B)

Gateshead, St. Mary (B)

$$
\because \quad \text { Holy Trinity (H) }
$$

Greatham, St. John the Baptist

Grindon, St. Thomas a Becket (B)

Hamsterley, St. James (B)

Hart, St. Mary Magdalen (B)

Hartlepool, St. Hilda (B)

Haughton-le-Skerne, St. Andrew (B)

Heighington, St. Michael (B)

Heworth, St. Mary

Houghton-le-Spring, St. Michael (B)

Hunstanworth, St. James (S)

Hurworth, All Saints (B)

Jarrow, St. Paul (B)

Kelloe, St. Helen (B)

Lamesley, St. Andrew

Lanchester, All Saints (B.), or St. Mary

Long-Newton, St. Mary (H)

Medomsley, St. Mary Magdalen (B)

Merrington, St. John the Evangelist (H) (St. John, B)

Middleton St. George, St. George (B)
Middleton-in-Teesdale, St. Mary the

Virgin

Monk-Hesleden, St. Mary (B)

Monk-Wearmouth, St. Peter (B)

Muggleswick, unnamed

Norton, St. Mary the Virgin (St. Mary, B)

Pensher, All Saints

Pittington, St. Laurence (B)

Redmarshall, St. Cuthbert (B)

Ryton, Holy Cross (B)

Sadberge, St. Andrew (H)

St. Andrew Auckland, St. Andrew (B)

St. Helen Auckland, St. Helen (B)

St. John Weardale, St. John the Baptist (St. John, B)

Satley, St. Cuthbert

Seaham, St. Mary (B)

Sedgefield, St. Edmund the Bishop (B)

Sherburn Hospital, Christ's

Sockburn, All Saints (B)

South Shields, St. Hilda (B)

Staindrop, St. Mary the Virgin (St. Mary, B)

Stainton-le-Street, All Saints (B)

Stanhope, St. Thomas the Apostle (B)

Stockton, St. Thomas (B), or St. Thomas of Canterbury (H)

Stranton, All Saints (B)

Sunderland, Holy Trinity

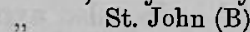

(See Bishop-Wearmouth and MonkWearmouth)

Tanfield, St. James (B), or St. Margaret (H)

Trimdon, St. Mary Magdalen (B)

Washington, St. Mary (S.)

Whickham, St. Mary (B)

Whitburn, St. Mary

Whitworth, unnamed

Whorlton, St. Mary

Winston, St. Andrew (B)

Witton-Gilbert, St. Michael (H)

Witton-le-Wear, St. Philip and St. James (B)

Wolsingham, St. Mary and St. Stephen (B), or St. Matthew

Wolviston, St. Peter (B) 